\title{
The effect of pretreatment on the nutritive value of diets for poultry
}

\section{By B. J. Wilson and J. M. McNab, Agricultural Research Council's Poultry Research Centre, King's Buildings, West Mains Road, Edinburgh EH9 $37 S$}

Poultry are offered feedstuffs which show considerable variability; for example those of plant origin may be affected by breed, soil conditions, fertilizer application and other variables. Feedstuffs are subjected to processes which are difficult to define by physical parameters in a way that would allow repetition of a particular set of circumstances. In these respects poultry are similar to other livestock. However, poultry differ importantly from other stock in some respects relevant to consideration of processing. Firstly, poultry are fed on a mixed diet, complex in its number of constituents. Secondly, some of the common feedstuffs, e.g. oilseed meals, are secondary or tertiary products and have been subject to processes which may not have been related to improving their nutritive value to poultry and over which the poultry compounder has had no control. Thirdly, some 'processes' are actually a combination of treatments. For example 'water treatment' commonly includes hot-air drying and grinding and 'micronizing' consists not only of heat treatment but also of flaking and possibly grinding and water addition. Finally, some processes, principally pelleting, are appiied to the whole mix of ingredients with the assumption that any effects observed experimentally when processing individual ingredients will be present proportionally when the whole mix is treated.

\section{Storage processes}

The effect of storage processes on raw materials has received scant attention. Bragg, Sharma \& Ingalls (1970) found that formalin treatment of wheat had no effect on body-weight unless the wheat was dried before diet preparation, when the subsequent reduction in food intake was attributed to odours. Moran, Summers \& Bass ( 1968 ) reported that gamma-irradiation of wheat bran at rates up to $5 \mathrm{Mrad}$ had no effect on metabolizable energy (ME) content, but improved net phosphorus utilization and retention. This effect was attributed to an alteration in the ester linkage of myo-inositol hexaphosphate.

\section{Grinding}

Ingredients in poultry diets are almost invariably ground, yet the effects of grinding and particle size are poorly described. A common finding (Poley, 1938; Berg \& Bearse, 1947; Nikolaiczuk, 1950; McIntosh, Slinger, Sibbald \& Ashton, $1962 a)$ is that fine particle sizes $(<0.5 \mathrm{~mm}$ diameter $)$ cause 'pressure necrosis' of 
the beak in young birds. Eley \& Bell (1948) and Eley \& Hoffman (1949) reported an inverse relationship between particle size and water intake. Wastage from the food trough was greater with large particles but much more food was recovered from the water trough on feedstuffs with fine particles, which adhere to the beak. Davis, Hill, Sloan \& Briggs (195I) offered a choice of particle sizes and reported a preferential selection of the largest $(2000-1410 \mu \mathrm{m})$. Since Smith, Carter, Brown \& Douglas (1968) found considerable variation in elemental composition among different-sized fractions of ground feedstuffs, such preferences may cause bias in nutrient intake. Feeding management should prevent such an effect from being other than a short-term phenomenon.

There is little evidence of the effect of grinding on nutritive value. Fritz (1935) found that diethyl ether extract digestibilities for whole, cracked or ground maize were $0.750,0.871$ and 0.913 respectively, while the digestibilities of other components were stable. More recently Mitchell, Waldroup, Hillard \& Hazen (1972) ground cooked full-fat soya beans into fine screen sizes and found that fat digestibility and nitrogen retention ranged from 0.577 to 0.900 and 0.528 to 0.617 respectively as fraction size fell from 480 to 20 .

\section{'Non-heat' treatments of individual feedstuffs}

Nutritive value may be raised by a pretreatment with water. Thus linseed meal is markedly improved by moistening and incubating overnight at $37^{\circ}$ (McGinnis \& Polis, 1946). Most research into water treatment has been directed at cereals, and barley has received greatest attention, probably because its low digestibility coefficients (Jakobsen, Gertov \& Nielsen, 1960; Vogt \& Stutz, 1971; Petersen, 1972) offer the greatest hope for improvement. Although there is convincing evidence from many laboratories that water treatment improves the nutritive value of barley to the chick the factors involved in the improvement are far from clear, particularly since the treatment is commonly combined with drying and grinding. Drying temperatures of $85-90^{\circ}$ are claimed to be best (Adams \& Naber, 1969) while higher temperatures reduce nutritive value (Anderson, Vojnovich \& Griffin, 1961). The improvement appears independent of the variety of barley and of its proximate analysis (Willingham, Jensen \& McGinnis, 1959). Novacek \& Petersen (1967) showed that the husk, pericarp, germ, aleurone and endosperm fractions of barley all respond slightly to water treatment, although the improvement with unfractionated barley was greater than was accounted for by the combined effects on the anatomical parts. Increased availability of energy is an outstanding feature of water-treated barley (Leong, Jensen \& McGinnis, 1962; Potter, Stutz \& Matterson, 1965; Novacek \& Petersen, 1967) and is attributed to breakdown of cellular carbohydrates or alteration in the structure of the intracellular starch (Fry, Allred, Jensen \& McGinnis, I958).

Enzyme addition to poultry diets is well documented but enzyme pretreatment is rare. However, Saunders \& Kohler (1972) pretreated wheat bran with cellulase (EC 3.2.1.4), which is claimed to hydrolyse the aleurone cell wall, and showed that estimates of protein digestibility in vitro rose from 0.70 to nearly 0.90 . 


\section{Heat treatment of individual feedstuffs}

Non-legumes. Hinders \& Eng (1970) reported considerable differences in the extent of gelatinization and availability of starch after cooking or micronizing different varieties of sorghum (Sorghum vulgare Pers.). These authors suggested that the structure of the starch granule and the protein matrix were the factors principally affecting the rate of starch degradation.

In the instance of maize most of the literature is aimed at the needs of the starch industry rather than of animal nutrition. In contrast, several groups have explored the growth-depressing effects of wheat-germ meal. Cave, Slinger \& Summers (1968) and El-Lakany, Biely \& March (I969) found an ME response of about 3 or $4 \%$ after autoclaving and Moran, Summers \& Bayley (1968) reported that the high antitrypsin and haemagglutinating activities of raw wheat-germ were overcome by toasting and autoclaving.

Legumes. Osborne \& Mendel (1917) recorded that certain plant protein foods were improved by heat treatment. This observation led to the recognition of a wide range of compounds which result in reduced performance (Liener, 1969). The most intensively investigated are the inhibitors of the proteolytic enzymes, trypsin and chymotrypsin, partly because of their ubiquity and partly because of their high concentrations in the commercially important soya bean. Other factors which are known to affect detrimentally the nutritive value of a feedstuff are haemagglutinins, amylase inhibitors, tannins, gossypol, phytates, goitrogens and saponins. Most of these factors are not generally relevant to commercial poultry nutrition. As recent reviews dealing with their modes of action are available (Couch \& Hooper, 1972; Liener, 1973, 1975) they will not be dealt with here.

Preoccupation with attempts to correlate responses to heat treatment with levels of anti-nutritive factors has tended to obscure the effects that heat can have on protein and carbohydrate components of legumes. Structural changes induced by heat may well result in an increase in the efficiency of digestion. Kakade (1974) has argued that the improved nutritive value of many protein-containing feedstuffs after heat treatment may, at least in part, be explained by the rupture of the threedimensional structure of the protein. Much of the study of legumes has involved autoclaving as the means of heat treatment, but this treatment is not of commercial significance. Micronizing is a new technique of heating to be applied to ingredients for poultry diets. It consists of heat treatment followed by rolling, flaking and grinding. The nutritive value of field beans (Vicia faba L.) is significantly improved by micronizing. Food conversion efficiency (FCE) ( $\mathrm{g}$ body-weight gain/g food intake), apparent protein digestibility and $\mathrm{N}$ retention are increased and pancreas size is reduced when chicks are fed on a diet containing micronized beans (McNab \& Wilson, 1974). D. W. F. Shannon (personal communication) obtained responses of a similar order after autoclaving field beans, which may suggest that there is little special about micronizing except that it is a commercially viable process. Studies with full-fat soya beans and with whole rapeseed show that micronizing is a ready means of obtaining safe high-energy feedstuffs. Another feature of micronized products can be a low moisture content with consequent improvement in keeping quality. 


\section{Pelleting}

Forming of diets into pellets or crumbles is routine in many types of poultry production and the effect of pelleting on individual feedstuffs or on mixed diets has been the subject of a great deal of research (see review by Calet, 1965).

The physical effects of pelleting a feedstuff are considerable. Hussar \& Robblee (1962) found that diet density increased from 0.57 to $0.71 \times 10^{3} \mathrm{~kg} / \mathrm{m}^{3}$ on pelleting while regrinding gave a density of $0.60 \times 10^{3} \mathrm{~kg} / \mathrm{m}^{3}$. Density changes are probably greatest in fibrous materials such as wheat by-products, which are bulky and may have awkward flow characteristics. Moisture content appears little affected by steam pelleting, being $100-140$ before and $150-220 \mathrm{~g} / \mathrm{kg}$ after conditioning by steam but returning to I IO-140 $\mathrm{g} / \mathrm{kg}$ after cooling (Bayley, Summers \& Slinger, 1968). The moisture imparted at conditioning is a function of time and of steam pressure, more moisture being taken up in the presence of low-pressure steam which has time to condense (MacBain, 1966). Bayley et al. (1968) noted that steam preconditioning for $3-5 \mathrm{~s}$ at a pressure of $4.57 \mathrm{~g} / \mathrm{mm}^{2}\left(9.8 \mathrm{I} \mathrm{kN} / \mathrm{m}^{2}\right)$ heated diet to a temperature of $90^{\circ}$ while Hussar \& Robblee (1962) found that pellet temperatures lay in the range $65-70^{\circ}$. Their finding that maximum die temperature was only reached after $15^{-25} \mathrm{~min}$ of pelleting should be borne in mind, particularly when pelleting short-run experimental diets.

There is considerable conflict among reports of nutritive value changes due to pelleting. Blakely, MacGregor \& Hanel (1963) found little effect of dry or steam pelleting on ME. It was also claimed (Bayley et al. 1968) that in experiments with wheat, maize and soya beans, ME differences could not explain observed growth responses. McIntosh et al. (1962a) found that ME of a diet containing $6 \mathrm{rog}$ of wheat $/ \mathrm{kg}$ was improved by about $9 \%$ after pelleting. However, they subsequently reported (McIntosh, Slinger, Sibbald \& Ashton, $1962 b$ ) that the ME value of cereal grains was not uniformly affected by the form of feeding. Summers, Bentley \& Slinger ( 1968 ) reported that the ME of wheat bran was improved by $30 \%$ after steam pelleting and Moran, Summers \& Jones ( 1968$)$ found that the ME of raw peas was improved from $10.3^{8}$ to $1 \mathrm{I} \cdot 30 \mathrm{~kJ}\left(2 \cdot 4^{8}\right.$ to $\left.2 \cdot 70 \mathrm{kcal}\right) / \mathrm{g}$ by pelleting, a response identical to that obtained by autoclaving. In recent work Janssen ( 1975 ) studied three wheat fractions with fibre contents of 133,94 and $36 \mathrm{~g} / \mathrm{kg}$ and found that absolute ME levels were inversely proportional, and improvement in ME and digestibilities of protein or fat were directly proportional to fibre level. The responses in $\mathrm{ME}$ are thus likely to reflect the scope for cellular disruption by the mechanical effects of pelleting. The importance of mechanical forces is emphasized by the work of Carew \& Nesheim (1962) which estimated that absorbability of oil in soya beans was raised from 0.73 to 0.78 by pelleting the beans but was improved to 0.90 by pelleting the beans in a mixed diet. The difference was attributed by the authors to the low pressures generated in pelleting the beans alone. A specific response observed by Summers, Slinger \& Cisneros (1967) was the improvement in plasma inorganic $P$ and bone ash levels in birds after pelleting a diet containing $250 \mathrm{~g}$ wheat $\mathrm{bran} / \mathrm{kg}$.

Although the effects of pelleting on nutritive value seem very variable there is 
widespread evidence of growth responses to pelleting. Undoubtedly these responses are largely due to increased food intake and to increased nutrient density. Reddy, Jensen, Merrill \& McGinnis ( $\mathrm{Ig62}^{2}$ ) incorporated cellulose in a pelleted diet to give nutrient density equal to that in a mash control diet and entirely removed the growth response to pelleting which they had observed. As well as increasing food intake, pelleting has other important effects. Jensen, Merrill, Reddy \& McGinnis ( 1962 ) found that poults fed on a mash or pellets used 18.8 and $2.2 \%$ of the day, respectively, for eating; corresponding values for chicks were 14.3 and $4.7 \%$. Fujita (1974) observed at similar food intakes that eating time was over $500 \mathrm{~min}$ for mash and between 100 and $200 \mathrm{~min}$ for pellets. A consequence of these effects is that several authors report that although ME responses may be small and erratic, there are large responses in dietary productive energy (PE) levels after pelleting (Reddy, Jensen, Merrill \& McGinnis, r96r ; Reddy et al. 1962). The response in PE is presumably due to the considerably increased ease of prehension of pellets over meals. With more time available an increase in vices may result from feeding pellets. Merritt, Downs, Bordeleau \& Tinney (1960), for example, report increased downgrading due to feather loss when giving pelleted diets.

Finally, pellet integrity may be improved by the use of binding agents, but little work has been done on their effects on nutritive value. Boza, Pintor \& Varela (1973) found that lignosulphonates appeared to reduce FCE. Morrison, Waldroup, Greene \& Stephenson (1968) assigned an ME value of $9.75 \mathrm{~kJ}(2.33 \mathrm{kcal}) / \mathrm{g}$ to a calcium lignosulphonate binder, but warned that loss of performance would result if used at levels above $4^{\circ}-50 \mathrm{~g} / \mathrm{kg}$ diet. They attributed the loss to diuresis caused by the high ash content $(75 \mathrm{~g} / \mathrm{kg})$ of the binder.

\section{REFERENCES}

Adams, O. L. \& Naber, E. C. (1969). Poult. Sci. 48, 853 .

Anderson, R. A., Vojnovich, C. \& Griffin, E. L. (196I). Cereal Chem. 38, 84.

Bayley, H. S., Summers, J. D. \& Slinger, S. J. (Ig68), Poult. Sci. 47, II40.

Berg, L. R. \& Bearse, G. E. (1947). Poult. Sci. 26, 532.

Blakely, R. M., MacGregor, H. I. \& Hanel, D. (1963). Br. Poult. Sci. 4, 261.

Boza, J., Pintor, D. \& Varela, G. (1973). Revta Nutr. anim. I1, 17.

Bragg, D. B., Sharma, H. R. \& Ingalls, J. R. (1970). Can. F. Anim. Sci. 50, 601.

Calet, C. (1965). Wld's Poult. Sci. F. 21, 23.

Carew, L. B. Jr. \& Nesheim, M. C. (1962). Poult. Sci. 4I, 16r.

Cave, N. A. G., Slinger, S. J. \& Summers, J. D. (Ig68). Can. F. Anim. Sci. 48, 199.

Couch, J. R. \& Hooper, F. G. (1972). In Newer Methods of Nutritional Biochemistry, vol. 5, p. 183 [A. A. Albanese, editor]. London: Academic Press.

Davis, R. L., Hill, E. G., Sloan, H. J. \&c Briggs, G. M. (1951). Poult. Sci. 30, 325.

El-Lakany, S., Biely, J. \& March, B. E. (I969). Cereal Chem. 46, 30r.

Eley, C. P. \& Bell, J. C. (I 948). Poult. Sci. 27, 660.

Eley, C. P. \& Hoffman, E. (1949). Poult. Sci. 28, 215.

Fritz, J. C. (1935). Poult. Sci. 14, 267.

Fry, R. E., Allred, J. B., Jensen, L. S. \& McGinnis, J. (1958). Poult. Sci. 37, 372.

Fujita, H. (1974). Jap. Poult. Sci. 10, 210.

Hinders, R. \& Eng, K. (1970). Feedstuffs, Minneap. 42, (March 7) 20.

Hussar, N. \& Robblee, A. R. (1962). Poult. Sci. 41, 1489. 
Jakobsen, P. E., Gertov, K. \& Nielsen, S. H. (1960). Beretn. Forsogslab. no. 322.

Janssen, W. M. M. A. (1975). Rep. Spelderholt Inst. Poult. Res., Beekbergen no. 9775.

Jensen, L. S., Merrill, L. H., Reddy, C. V. \& McGinnis, J. (1962). Poult. Sci. 41, I4I4.

Kakade, M. L. (1974). F. Agric. Fd Chem. 22, $55^{\circ}$.

Leong, K. C., Jensen, L. S. \& McGinnis, J. (1962). Poult. Sci. 41, 36.

Liener, I. E. (editor) (1969). Toxic Constituents of Plant Foodstuffs. New York and London: Academic Press.

Liener, I. E. (1973). In Proteins in Human Nutrition, p. 481 [J. W. G. Porter and B. A. Rolls, editors]. New York and London: Academic Press.

Liener, I. E. (1975). Animal Feeds of Tropical and Sub-tropical Origin, p. 179 . London: Tropical Products Institute.

MacBain, R. (1966). Pelleting Animal Feed, p. 1. Arlington, Virginia: American Feed Manufacturers Association.

McGinnis, J. \& Polis, H. L. (1946). Poult. Sci. 25, 408.

McIntosh, J. I., Slinger, S. J., Sibbald, I. R. \& Ashton, G. C. (1962a). Poult. Sci. 41, $43^{8}$.

McIntosh, J. I., Slinger, S. J., Sibbald, I. R. \& Ashton, G. C. (1962b). Poult. Sci. 4 I, 445.

McNab, J. M. \& Wilson, B. J. (1974). F. Sci. Fd Agric. 25, 395.

Merritt, E. S., Downs, J. H., Bordeleau, R. \& Tinney, B. F. (1960). Can. J. Anim. Sci. 40, 7.

Mitchell, R. J., Waldroup, P. W., Hillard, C. M. \& Hazen, K. R. (1972). Poult. Sci. 51, 506.

Moran, E. T., Summers, J. D. \&e Bass, E. J. (1 968). Cereal Chem. 45, 304.

Moran, E. T., Summers, J. D. \& Bayley, H. S. (1968). Cereal Chem. 45, 469.

Moran, E. T., Summers, J. D. \& Jones, G. E. (1968). Can. J. Agric. Sci. 48, 47.

Morrison, H. L., Waldroup, P. W., Greene, D. E. \& Stephenson, E. L. (1968). Poult. Sci. 47, 592.

Nikolaiczuk, N. (1950). Poult. Sci. 29, 773.

Novacek, E. J. \& Petersen, C. J. (1967). Poult. Sci. 46, 1008.

Osborne, J. B. \& Mendel, L. B. (1917). f. biol. Chem. 32, 369.

Petersen, V. E. (1972). In Cereal Processing and Digestion, p. 67. London: US Feed Grains Council.

Poley, W. E. (1938). Poult. Sci. 17, 331.

Potter, L. M., Stutz, M. W. \& Matterson, L. D. (1965). Poult. Sci. 44, 565.

Reddy, C. V., Jensen, L. S., Merrill, L. H. \& McGinnis, J. (1961). Poult. Sci. 40, 1446.

Reddy, C. V., Jensen, L. S., Merrill, L. H. \& McGinnis, J. (1962). F. Nutr. 77, 428.

Saunders, R. M. \& Kohler, G. O. (1972). Cereal Chem. 49, 98.

Smith, J. H., Carter, D. L., Brown, M. J. \& Douglas, C. L. (1968). Agron. J. 60, 149.

Summers, J. D., Bentley, H. U. \& Slinger, S. J. (1968). Cereal Chem. 45, 6r2.

Summers, J. D., Slinger, S. J. \& Cisneros, G. (1967). Cereal Chem. 44, 318.

Vogt, H. \& Stutz, K. (1971). Arch. Geflügelk. 35, 29.

Willingham, H. E., Jensen, L. S. \& McGinnis, J. (1959). Poult. Sci. 38, 539. 